\title{
Organisational Citizenship Behaviour and Quality of Work Life Balance among Educationalist and Hospital Workers
}

\author{
K. Ramalakshmi, Selvarani Mariappan
}

\begin{abstract}
The present examination was directed to look at the connection between organisational citizenship conduct and worklife balance. The investigation led among two distinct segment sin Tirunelveli region and the information were gathered from 101 representatives of teaching faculties and hospital workers. The organized survey was utilized to gather the information from respondents. 20 authoritative citizenship conduct sizes of Suzy fox and paul $E$ Spector have been incorporated into this investigation. Gathered information were investigated through expressive measurements and cross tabulation was utilized for dissecting the information.
\end{abstract}

Key words: Organisational Citizenship Behaviour, Work Life Balance, Employee Commitment, Employee Stisfaction

\section{INTRODUCTION}

$\mathrm{T}$ his Organizational citizenship behaviour is the term considered since 1970s. Authoritative conduct is imperative for in general hierarchical adequacy. Authoritative citizenship is an idea that all ventures want to have yet exceptionally few can really accomplish. It is dug in individual representatives' perspective on the organization and how they relate themselves with it. Most representatives perceive that their significant obligation is to carry out the responsibility that is alloted to them, keep on far from practices that could be seen as inconvenient, and bring work that is attractive and supportive to the association Usually, these practices are viewed as idealistic by chiefs and business administrators, and the extent and crash of these practices ought to be noted. Associations are always searching for workers who control the practices and rules that cosmetics Organizational Citizenship Behaviors. Be that as it may, administrators and authorities can help to help these practices which ought to optimistically affect society and responsibility. Association require to exhibit the kinds of practices they need workers to take on. Societies are set up at the top, and if work see authoritative supervisors being thoughtful, help other people when they can, including in exercises external side of work, arranging philanthropy procedures supported by the

Revised Manuscript Received on July 22, 2019.

* Correspondence Author

K.Ramalakshmi *, Research scholar, Kalasalingam Business School, Kalasalingam Academy of Research and Education, Krishnan Koil , Tamil

Selvarani Mariappan, Department of Business Administration Kalasalingam Business School, Kalasalingam Academy of Research and Education, Krishnan Koil, Tamil Nadu India, selvarani@klu.ac.in Nadu India , Email.iamlakshmimba@gmail.com

association, at that point specialists will effectively partake in Organizational Citizenship Behaviour. Each factor of Organizational Citizenship Behaviour should connected with hierarchical objectives and qualities benevolence, affability, reliability, sportsmanship, and urban activity are the different factors of OCB. These factors would prefer not to be named as equivalent or referenced straight, however the characteristics of this nature direction ought to be joined in any verbiage that impart to organization objectives or destinations. This will advance a culture spoken to by OCBs. At the point when given the chance, representatives needed to have some opportunity to choose to be compassionate, show graciousness, be industrious, have sportsmanship, or take part in municipal goodness.

In the present workplace representatives are having more commitments, for example, family and work. Family may incorporate youngsters, and older parent care. Work life equalization implies the parity required among time designated for work and different parts of life. And furthermore work life is the business exercise of making, adaptable and accommodating condition to associate representatives and increment hierarchical execution of the representatives. Numerous investigations have been led on work life balance. As indicated by Lowe 2005 one out of four representatives confronting more clash among work and family. Protracted work hours and very successful are fine and satisfactory.

Occupations not just hinder worker capacity to fit work and family yet in addition related with wellbeing danger, for example, weight increase and misery. The association can improve their representatives work life balance in the accompanying ways, dissect the need of the workers, give instruction to representatives, decrease burnout, offering help to media transmission, empower the official work of the workers and elevate wellbeing motivation to workers. A superior work life equalizationcan encourage the representatives to think about additional responsible for their working life and lead to effectiveness, work participation, improvement in worker well being and prosperity. Rganisation today can't disregard the significance or issues of work life balance.

For whatever length of time that worker's adaptability to address singular duties, without arranging the necessities of the business, can make the uniqueness between a decent workplace. 
Work life equalization is an idea including legitimate prioritization among work and way of life

Family: The exercises accomplished for the individuals from the family that are obligations - not play.

Work: Duties performed for boss at work spot not at home.

\section{PURPOSE OF THE STUDY}

An investigation on organisational citizenship conduct and work life approach is entirely fundamental in the present situation. Nature of work life fills in as forecaster for hierarchical citizenship conduct in late workplace representatives need to balance out their family and work. In an undertaking an examination on relationship among OCB and work life parity dive in. Keeping up the Integrity of the Specifications..

\section{REVIEW OF LITERATURE}

The idea of OCB was first prescribed by Organ (1988,) who clarified it as an intentional exertion by the people, it isn't portrayed part of their expected set of responsibilities in addition it isn't determined in their formal reward framework. OCB generally is found to exist in workers with raised hierarchical responsibility. Past research has perceived a few extents of OCB, for example, charitableness, good faith and utilitarian contribution (Dyne et.al. 1994).The model created by Fisher-McAuley, Stanton, Jolton and Gavin (2003) is one such structure. They have presented three measurements in particular: Work obstruction with individual life (WIPL the impedance of work and individual life), Personal life impedance with work (PLIW obstruction of individual existence with work) and finally work/individual life improvement (WPLE upgrading work through close to home life). WPLE is an extreme condition.

Hamid Reza Qasemi, Milad Behadi (2017). Investigated the interceding job of association work family advancement between association Intervening and authoritative citizenship conduct, variable in parts of mellat bank of Iran. In this examination regarding target is a connected research and as far as usage approach is easygoingexploration. granbach's alpha and congruity factor investigation was utilized in this examination. 300 examples were gathered for this examination the effect of factors of work family advantages and approaches and the board backing was affirmed in this investigation.

KOPP Lauren, R. (2013) Eramined the impacts of apparent colleague and administrator social help un representative work life balance, work fulfillment, Organizational responsibility, and authoritative citizenship practices. The example were gather from 132 members the investigation additionally decide whether saw work life backing is emphatically identified with full of feeling and conduct result found that administrator backing anticipated certain representative result is more than colleague support.

Makiah, et.al (2018). Broke down and know the impact of work life equalization and work place spiuality on OCB. The number of inhabitants in the examination is 363 . Test criteria were utilized for this examination is instructors conceived in 1980-2000. Straightforward arbitrary inspecting was in this examination. The investigation examination just factors influencing $\mathrm{OCB}$ in this examination considers just work life balance, work place otherworldliness and authoritative responsibility, yet there are numerous other factor that can influence OCB.

Rabinda Kumar Pradhan etal. (2016). As indicated by this examination Balancing work and life remains as a continuous test in contemporary occasions. The examination reports the noteworthy impact of work life balance and organisataional citizenship conduct. The investigation directed among the representatives and executies of assembling businesses in eastern India. Work life parity of this investigation is social need, individual need, Time the board, Team work. OCB factors of this examination is Altruism conscientiaistion curtesy, common prudence, sportsmanship. The investigation discoveries should that WLB is altogether intervened with the components of OC.

Thavancs N. Mangaleswaran. T (2018). Goal of the investigation is to test the connection between work life parity and employment execution. The information were gathered from 166 representatives of chose private banks in Batticerloa area of Sri Lanka gathered information were broke down through univariate and bivariate investigations. The ifuly that work-life parity has positive and critical association with Job execution.

H.Dwivedi, Samankhan. (2018) examined the connection among OCB and work life balance in contact of Indian working educators. The review was done on 220 Female academicians of Northern India working in advanced education Institutes aftereffect of the examination demonstrates that OCB and WLB having moderate connection between them. AMOSS 23 was utilized in this study

\section{OBJECTIVE OF THE STUDY}

1. To analyse the demographic profile and its relationship with OCB and Quality of Work life.

2. To identify the level of OCB and QWL among Teaching faculties, and Nurses.

3. To assess the relationship between organisational citizenship conduct and work life balance.

\section{RESEARCH DESIGN OF THE STUDY}

Demographic data were gathered from 101 representatives of training division and social insurance branch of Tirunelveli region. Comfort examining has been embraced for this investigation 20 authoritative citizenship conduct Scales of Suzy Fox and Paul E Spector have been incorporated into this examination. Netameyer, Boles and Mcmurrian Scales were utilized for work life and family clashes. 


\section{ANALYSIS AND FINDINGS}

Table 6.1 Demographic Profile

\begin{tabular}{|c|c|c|}
\hline Gender & Frequency & $\%$ \\
\hline Male & 45 & 45 \\
\hline Female & 55 & 55 \\
\hline Age & Frequency & $\%$ \\
\hline 23 - 30 years & 18 & 18 \\
\hline $31-40$ years & 44 & 44 \\
\hline $41-50$ years & 22 & 22 \\
\hline above 50 years & 16 & 16 \\
\hline Marital status & Frequency & $\%$ \\
\hline Single & 29 & 29 \\
\hline Married & 58 & 58 \\
\hline Widow & 11 & 11 \\
\hline Separated & 2 & 2 \\
\hline Education & Frequency & $\%$ \\
\hline High school & 4 & 4 \\
\hline Higher secondary & 18 & 18 \\
\hline Under graduate & 20 & 20 \\
\hline Post graduate & 14 & 14 \\
\hline M Phil & 25 & 25 \\
\hline $\mathrm{PhD}$ & 19 & 19 \\
\hline Income & Frequency & $\%$ \\
\hline Less than 15000 & 21 & 21 \\
\hline $15001-20000$ & 25 & 25 \\
\hline $20001-30000$ & 15 & 15 \\
\hline $30001-40000$ & 17 & 17 \\
\hline Above 40000 & 22 & 22 \\
\hline $\begin{array}{l}\text { Nature of } \\
\text { employment }\end{array}$ & Frequency & $\%$ \\
\hline Fulltime & 47 & 47 \\
\hline Part time & 29 & 29 \\
\hline Temporary & 24 & 24 \\
\hline $\begin{array}{l}\text { Nature of } \\
\text { Organisation }\end{array}$ & Frequency & $\%$ \\
\hline Hospital & 61 & 61 \\
\hline Educational Institution & 39 & 39 \\
\hline Experience & Frequency & $\%$ \\
\hline 4-6 years & 53 & 53 \\
\hline 7-9 years & 32 & 32 \\
\hline More than 9 years & 15 & 15 \\
\hline Family size & Frequency & $\%$ \\
\hline Less than 3 members & 10 & 10 \\
\hline 3-5 members & 49 & 49 \\
\hline 6-8 members & 34 & 34 \\
\hline More than 8 members & 7 & 7 \\
\hline
\end{tabular}

Findings of the investigation demonstrates that out of 101 workers $45 \%$ of representatives are Male and 55\% of are female, based on age savvy 30 years, $44 \%$ of respondent are gone under $31-40$ years, $21 \%$ of respondent are gone under 41-multi year, $16 \%$ of the respondents are gone under the age gathering of over 50 years. What's more, another characterization is conjugal status of the representative $58 \%$ of them wedded $29 \%$ of them are not hitched, $11 \%$ are widow, and remaining $2 \%$ are isolated. Training is the another significant arrangement, which would characterize the degree of instruction of the representative under this characterization $4 \%$ of the respondents are done their High school, $18 \%$ of them are finished their higher secondary, $20 \%$ of them are finished their under graduation $14 \%$ of them are finished their post graduation, $25 \%$ of them are having M.Phil and staying $19 \%$ are having $\mathrm{PhD}$. As per the salary level of workers the vast majority of the representatives are gaining 15001-20001. And furthermore $53 \%$ of representatives are having 4-6 years of experience, increasingly over $49 \%$ of the workers are has a place with 3-5 individuals family measures.

TABLE 6.2 Mean aand Standard Deviation for OCB.

\begin{tabular}{|l|r|r|}
\hline Items & Mean & Mean Std. \\
\hline OCB15 & 4.66 & 0.49686 \\
\hline OCB8 & 4.64 & 3.9912 \\
\hline OCB10 & 4.31 & 0.77453 \\
\hline OCB11 & 4.25 & 0.95743 \\
\hline OCB7 & 4.1 & 1.01005 \\
\hline OCB9 & 4.08 & 1.04137 \\
\hline OCB17 & 4 & 1.04447 \\
\hline OCB5 & 3.87 & 1.00156 \\
\hline OCB12 & 3.67 & 1.10147 \\
\hline OCB4 & 3.65 & 1.09521 \\
\hline OCB6 & 3.65 & 1.1404 \\
\hline OCB16 & 3.62 & 1.0804 \\
\hline OCB2 & 3.57 & 1.35777 \\
\hline OCB3 & 3.53 & 1.13222 \\
\hline OCB13 & 3.51 & 0.81023 \\
\hline OCB20 & 3.41 & 1.4291 \\
\hline OCB1 & 3.15 & 0.93609 \\
\hline OCB18 & 2.96 & 1.30979 \\
\hline OCB19 & & 1.11028 \\
\hline OCB14 & 2.62 & 0.69311 \\
\hline
\end{tabular}

As indicated in table 6.2 the representative is having great assessment about the association. That OCB fifteenth thing is getting increasingly mean worth and exclusive expectation deviation. In that the mean worth is4.66 and standard deviation is 0.49686 . What's more, the second one which is getting increasingly mean worth is OCB 8 , In which worker is giving recommendations improve the work angle in which representatives listened closely when somebody had a work issue. 
Be that as it may, a few things of OCB are getting less significance just, on the grounds that the representatives are not having much enthusiasm towards the exercises like improvement fixed up or generally enhanced normal work space.

Table 6.3 Cross tabulation for Nature of organisation and Job satisfaction

\begin{tabular}{|c|c|c|c|c|c|c|c|}
\hline & \multicolumn{7}{|c|}{ Job Satisfaction } \\
\hline $\begin{array}{c}\text { Nature of } \\
\text { organization }\end{array}$ & & $\begin{array}{c}\text { Highly } \\
\text { dissatisfied }\end{array}$ & $\begin{array}{c}\text { Not } \\
\text { Satisfied }\end{array}$ & Neutral & Satisfied & $\begin{array}{c}\text { Highly } \\
\text { Satisfied }\end{array}$ & Total \\
\hline Hospital & Count & 3 & 2 & 7 & 19 & 30 & 61 \\
\hline & $\%$ & $4.9 \%$ & $3.3 \%$ & $11.5 \%$ & $31.1 \%$ & $49.2 \%$ & $100.0 \%$ \\
\hline $\begin{array}{l}\text { Educational } \\
\text { Institution }\end{array}$ & Count & 0 & 2 & 6 & 20 & 11 & 39 \\
\hline & $\%$ & $.0 \%$ & $5.1 \%$ & $15.4 \%$ & $51.3 \%$ & $28.2 \%$ & $100.0 \%$ \\
\hline Total & Count & 3 & 4 & 13 & 39 & 41 & 100 \\
\hline & $\%$ & $3.0 \%$ & $4.0 \%$ & $13.0 \%$ & $39.0 \%$ & $41.0 \%$ & $100.0 \%$ \\
\hline
\end{tabular}

Table 6.4 Cross Tabulation for family size and Work Family Conflict

\begin{tabular}{|c|c|c|c|c|c|c|c|c|c|}
\hline \multirow[b]{2}{*}{ Family size } & & \multicolumn{7}{|c|}{ WAFC } & \multirow[b]{2}{*}{ Total } \\
\hline & & $\begin{array}{c}\text { Very strongly } \\
\text { disagree }\end{array}$ & $\begin{array}{l}\text { Strongly } \\
\text { disagree }\end{array}$ & Disagree & $\begin{array}{l}\text { Neither agree } \\
\text { nor disagree }\end{array}$ & Agree & $\begin{array}{l}\text { Strongly } \\
\text { Agree }\end{array}$ & Very & \\
\hline \multirow[b]{2}{*}{$\begin{array}{l}\text { Less than } \\
3 \text { members }\end{array}$} & Count & 5 & 5 & 0 & 0 & 0 & 0 & 0 & 10 \\
\hline & $\%$ & $50.0 \%$ & $50.0 \%$ & $.0 \%$ & $.0 \%$ & $.0 \%$ & $.0 \%$ & $.0 \%$ & $100.0 \%$ \\
\hline \multirow[t]{2}{*}{$3-5$ members } & Count & 8 & 12 & 22 & 2 & 3 & 1 & 1 & 49 \\
\hline & $\%$ & $16.3 \%$ & $24.5 \%$ & $44.9 \%$ & $4.1 \%$ & $6.1 \%$ & $2.0 \%$ & $2.0 \%$ & $100.0 \%$ \\
\hline \multirow[t]{2}{*}{ 6-8 members } & Count & 2 & 14 & 9 & 5 & 2 & 1 & 1 & 34 \\
\hline & $\%$ & $5.9 \%$ & $41.2 \%$ & $26.5 \%$ & $14.7 \%$ & $5.9 \%$ & $2.9 \%$ & $2.9 \%$ & $100.0 \%$ \\
\hline \multirow{2}{*}{$\begin{array}{c}\text { More than } 8 \\
\text { members }\end{array}$} & Count & 3 & 4 & 0 & 0 & 0 & 0 & 0 & 7 \\
\hline & $\%$ & $42.9 \%$ & $57.1 \%$ & $.0 \%$ & $.0 \%$ & $.0 \%$ & $.0 \%$ & $.0 \%$ & $100.0 \%$ \\
\hline
\end{tabular}

In this examination two distinct Industries were incorporated for this investigation In which the representatives the individuals who are working in medical clinics exceedingly happy with their work and association contrasted with instruction division. Be that as it may, in which $3.3 \%$ of the representatives are not happy with their workplace and $4.9 \%$ of the representatives are profoundly dis happy with their workplace yet a large portion of the representatives are exceedingly happy with their work and association. If there should be an occurrence of instructive Institution out of $100 \%$ just $28.2 \%$ of them are exceptionally happy with their Job, there is no very disappointed people in training industry.

Table 6.5 demonstrates the connection between work life family strife and family size of the representatives. As indicated by the above table the individuals the individuals who has a place with 3 to 5 individuals family are exceedingly happy with their family and work that justify the values

Table 6.5 Mean and Standard Deviation for Work and Family Conflict

\begin{tabular}{|c|c|c|}
\hline \multicolumn{1}{|c|}{ Items } & Mean & Std. Deviation \\
\hline WAFC3 & 5.02 & 1.28692 \\
\hline WAFC2 & 4.9 & 1.37437 \\
\hline
\end{tabular}

\begin{tabular}{|r|l|l|}
\hline WAFC1 & 3.92 & 1.72726 \\
\hline WAFC10 & 3.42 & 1.54515 \\
\hline WAFC7 & 3.34 & 1.41578 \\
\hline WAFC4 & 3.11 & 1.49676 \\
\hline WAFC5 & 3.06 & 1.5097 \\
\hline WAFC6 & 2.6 & 1.30268 \\
\hline WAFC8 & 2.49 & 1.09632 \\
\hline WAFC9 & 2.08 & 1.22003 \\
\hline
\end{tabular}

\section{CONCLUSION}

In discoveries of this examination show apparent work-life balance between colleagues are emphatically identified with different employee results. Work life equalization has critical constructive outcome on OCB and authoritative responsibility; the better the work-life balance in a given firm, prompts improve the activity execution of representatives. Additionally the representatives the individuals who are working in medical clinic is profoundly happy with their activity and working conditions. However, if there should be an occurrence of instruction office representatives are not exceedingly fulfilled, in this circumstance the instruction office can find a way to improve the fulfillment level of the workers, they can give preparing to the workers, and

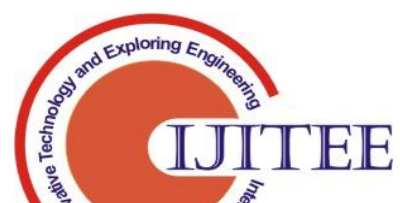


they can orchestrate persuasive classes to the representatives

\section{REFERENCES}

1. Anindita Bose Guha, Niraj Kishore Chimote. (2012). Exploring The Relationship Between Organizational Commitment, Organizationa Citizenship Behaviour And Work Life Balance. Indian Journal of Commerce \& Management Studies. Volume III Issue. ISSN : 2249-0310 EISSN: 2229-5674.

2. Arif Partono Prasetio, Tjutju Yuniarsih, Eeng Ahman. (2017). Perceived Work-Life Interface and Organizational Citizenship Behaviour: Are Job Satisfaction and Organizational Commitment Mediates the Relations? (Study on Star Hotels Employees in Indonesia). International Journal of Human Resource Studies, ISSN 2162-3058, Vol. 7, No. 2.

3. Ayesha Noor. (2009). Examining Organizational Citizenship Behavior As The Outcome Of Organizational Commitment: A Study Of Universities Teachers Of Pakistan. Proceedings 2nd CBRC, Lahore, Pakistan.

4. Hamid Reza Quasemi, Milad Behzadi (2017). "The mediating role of work family enrichment

between organizational Intervening and organizational citizenship behaviour : (ask study: Banking sector). Journal of Human Resource Management, Science publishing group, ISSN: 2331-0707.

5. Harikaran Thevanes (2018). "The relationships among work-life balance, organizational citizenship behaviour and organizational performance: A review of literature. IOIR Journal of Business and Management, volume 20, Issue8. Ver V.

6. Koop Lauren. R (2013). "The effort of perceived Supervisor work life support on Employee work Life Balance, job satisfaction, organizational commitment and organizational citizenship behaviour American Psychology Association edition.

7. Mohammad Ghasemi1, Naser Khodizaee, Abdolaziz Bady Cherakhi, Ali Rodbari, Zahra Kohkan. (2016). Analyze the Relationship between QWL and Organizational Citizenship Behavior Zabol University. Journal of Global Pharma Technology. ISSN 0975 - 8542

8. Makiah etal (2018). "Effect of work life balance, work place spirituality of organizational citizenship behaviour through organizational commitment as intervening variables. International journal of Economics, commerce and Management, volume. VI, Issue 7, ISSN 23480386, United kingdom.

9. Rabindra kumar Pradhan (2016). "Effect of work-life balance on organizational citizenship behaviour: Role of organizational commitment. Global business Review sage publications IT (35) 155-295.

10. ThevaneSN, Mangaleswaram. T. (2018). "Relationship between work-life balance and job performance of Employees". IOIR Journal of business and management, volume 20, Issue 5, www.iosrjournals.org.

11. Organ, D. W. (1997). Organizational citizenship behavior: It's construct cleanup time. Human Performance, 10(2), 85-97.

12. Organ, D. W., Podsakoff, P. M., \& MacKenzie S. P. (2006) Organizational citizenship behavior: Its nature, antecedents, and consequences. London: Sage Publications.

13. Podsakoff, N. P., Blume, B. D., Whiting, S. W., \& Podsakoff, P. M. (2009). Individual- and organizational-level consequences of organizational citizenship behaviors: A meta-analysis. Journal of Applied Psychology, 94(1), 122-141.

14. .Rabindra Kumar Pradhan, Lalatendu Kesari Jena, Itishree Gita Kumari. (2016). Effect of Work-Life Balance on Organizational Citizenship Behaviour: Role of Organizational Commitment. SAGE Publications ,Global Business Review 17(3S) 1S-15S.

15. .Shailendra Kumar.Chaturvedi and Hari Mohan Saxena. (2017). Impact of quality of work life on organizational citizenship behavior (OCB) with reference to higher education teachers in Lucknow City. Interrnational journal of Applied Research, 3(7): 395-399, ISSN Print: 2394-7500, ISSN Online: 2394- 5869

16. Shno mohamad, S.Kimuarsi, S.M.Hahem. (2016). Organisational Citizenship among the employees in private universities. International journal of business and innovation, Vol2, Issue6.

17. .http://www.qld.gov.au/health/mental-health/lifestyle.

18. .http:// www.zenefits.com.

19. http://www.webmd.com

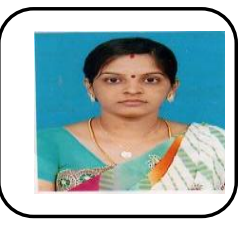

\section{AUTHORS PROFILE}

K.Ramalakshmi, Research scholar, Kalasalingam business school, Department of Business Administration, Kalasalingam university. Tamilnadu India. Email iamlakshmimba@gmail.com

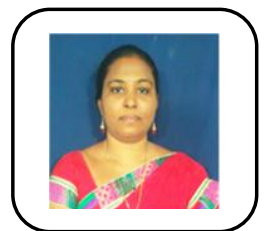

SelvaraniMariappanis currently working in Kalasalingam Business School, Kalasalingam Academy of Research and Education (Kalasalingam deemed to be University). She completed MBA from MepcoSchlenk Engineering College, India and ICWA Inter. She obtained her Doctorate from Kalasalingam University and is a researcher and teacher in the area of finance for more than 16 years. She expertise in stock market behavioral research and underwent FDP program on Econometrics in IIM, Kozhikode and published more research papers in a SCOPUS indexed journal and reviewer of finance journals. She contributed her research work as chapters in books. She writes extensively and presented papers in International and National Conference organised by IIT, IIM's and publishes scholarly works and case study. She got trained by Infosys on Global Business Foundation Skill and NIT on Analytics. She conducted FDP, Workshop and gave guest lecture to Students, employees and research Scholars. She acted as a BOS member for SFR College, Sivakasi. She got awards for her competency in teaching for two times and faculty advisory ship from IQAC, KARE. 